\title{
Experience from ILEC's project on Environmental Education
}

\author{
Sven E. JØRGENSEN \\ Institute A, DFH, Section of Environmental Chemistry, University Park 2, 2100 Copenhagen Ø, Denmark \\ Chairman of the Scientific Committee of ILEC, Shiga, Japan \\ e-mail: sej@dfuni.dk
}

\begin{abstract}
The experience of the ILEC's educational project is presented. The main conclusion from the project is that lakes can be applied as good educational illustrations of environmental issues due to the following seven points: lakes are typical ecosystems, lakes illustrate very well the hydrological cycles, lakes have a clear borderline, openness of an ecosystem is well illustrated by lakes, the recreational value of lakes is very clear, damage by pollutants can easily be illustrated by lakes, the social-economic value of lakes is very obvious.
\end{abstract}

Key words: environmental education, ecosystems, school project, ILEC (International Environment Committee)

\section{INTRODUCTION}

ILEC, the International Lake Environment Committee, launched in 1988 a school project with the idea to apply lakes as illustration of important issues in environmental education. The project gained experience on how lakes could be applied as the focal point in environmental education in seven countries: Japan, China, Thailand, Ghana, Argentina, Brazil and Denmark. The obtained results of the project are published in Jørgensen et al. (1997). The conclusion of the project is that lakes can indeed be applied as excellent illustrations of the most important issues and problems in environmental education. This conclusion is valid for education on all levels, although the project was mainly dealing with children of the 6-9 grade, i.e. from 12-16 years old.

Below is given the answer to the core question of the project: why are lakes excellent illustrations of environmentally important issues? The answers may be given in the following seven points:

- lakes are typical ecosystems;

- lakes illustrate very well the hydrological cycles;

- lakes have a clear borderline;

- openness of an ecosystem is well illustrated by lakes;

- the recreational value of lakes is very clear;

- damage by pollutants can easily be illustrated by lakes;

- the social-economic value of lakes is very obvious.

The details of these seven answers to the core question are given below in seven sections.

\section{LAKES ARE TYPICAL ECOSYSTEMS}

Because of the clear borderline between a terrestrial and an aquatic ecosystem (see Figure 1), it is very clear that the organisms in a lake are more interdependent than they are dependent on the organisms on land. The processes characteristic for the functioning of the lake make up a network where the nots are various organisms with characteristic properties. A food net can easily be found in a lake: nutrients -phytoplankton - zooplankton - small fish - big carnivorouse fish. Moreover, the cycling of the important elements nitrogen, carbon, phosphorus and so on is easily perceived: the transfer through the food chain produces detritus which is mineralized and the nutrients are recovered. The lake is instantly conceived as an entity.

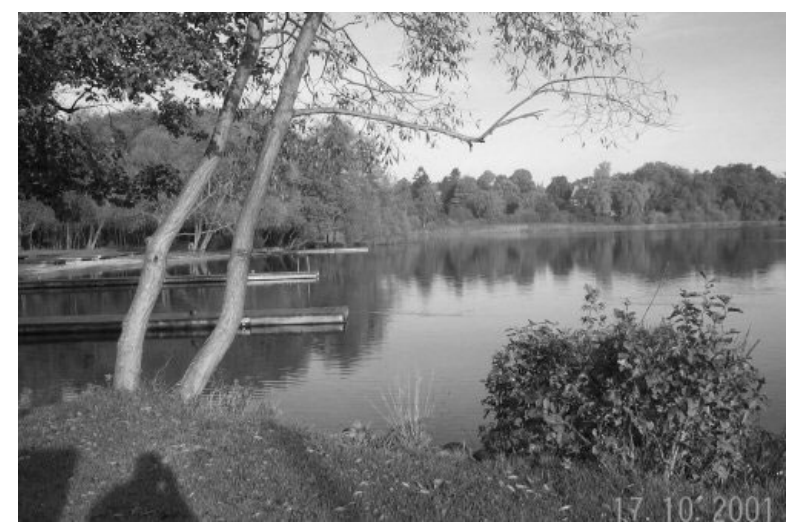

Fig. 1. Lakes have often clear borderline to other types of ecosystems as for instance on the figure, where the borderline between the forest surrounding the lake and the lake is easily found.

\section{LAKES ILLUSTRATE VERY WELL THE HYDROLOGICAL CYCLES}

A very reliable supply of good quality water is cumpolsory in a modern society. It implies that the society must erect water works and wastewater treatment plants to ensure the water supply and that discharge of the used water does not cause harmfull effects on the receiving water. Visits to these installation illustrate the water cycle in the society: surface water or ground water - do- 
mestic, agricultural or industrial use - wastewater treatment before discharge to surface water.

Figure 2 illustrates the importance of the protection of the water sources. The shown sign is at the shoreline of a Danish lake applied for water supply. Denmark is fortunate to have sufficient of good quality ground water. It is only in the Copenhagen area necessary to use surface water which is very protected against contamination. The lake was included in the lake school project and convinced the school children of the importance of the drinking water quality.

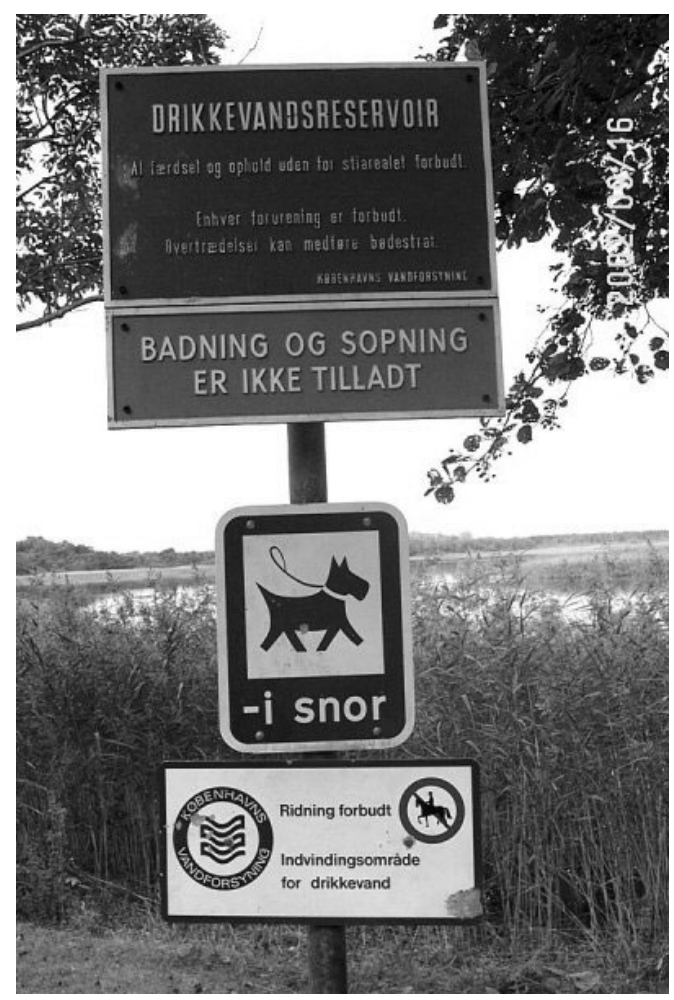

Fig. 2. The signs shown are at the shoreline of a Danish lake that is used as water resource for production of drinking water. The signs have the following text. This is a drinking water reservoir. All contamination of the water is strictly prohibited. Fines will be given by violation. Swimming and all kind of bathing in the water is not allowed. Riding is prohibited. Dogs must be kept in strings.

Where comes the water from? An answer to this question leads to nature's hydrological cycle: Precipitation directly on the land and the lake - drainage water rivers - the sea - evaporation - precipitation etc.

\section{LAKES HAVE A CLEAR BORDERLINE}

It is easy to see the borderline between water and land, between terrestrial ecosystems adn aquatic ecosystems. The borderline illustrates at the same time the line where land and water can exchange matter and energy, while the lake surface shows the area of exchange between the atmosphere and the lake. It is obvious that the (human) activities at the shoreline of a lake is of ut- most importance for the health of the lake and that a buffer zone (often a wetland) between land and the lake reduce the vulnerability of the lake to the shore activities. Figure 3 illustrates a typical ecotone as the transition system between two different ecosystems is named. The protection of the lake by a shore ecotone can be compared with the membranes for the cells and the skin for human being.

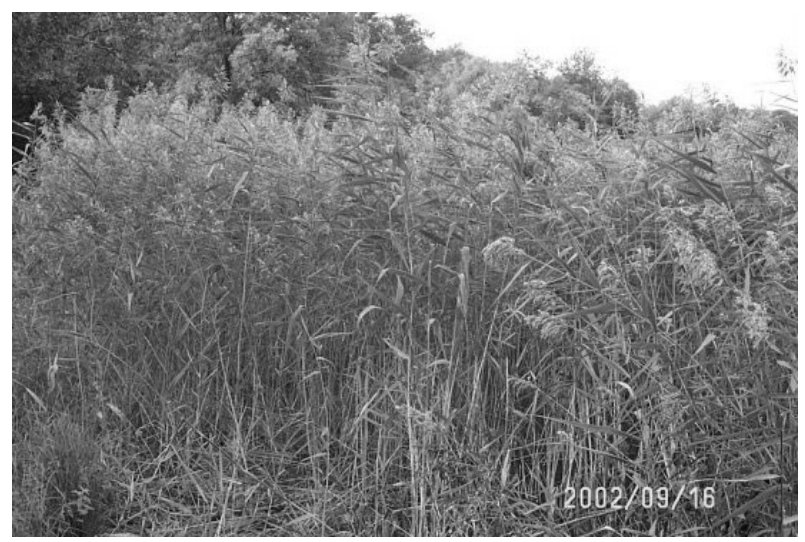

Fig. 3. A reed-swamp between a lake and its surrounding environment form a transition system between two ecosystems, named an ecotone.

\section{LAKES ARE OPEN SYSTEMS}

The openness of lakes is very easily shown: the inflows, rains, sunshine, outflows and so on. It may even be possible to find inflows of drainage water. Under all circumstances it is clear that the openness implies possibilities for pollutions. It is often a good illustration to collect rain water ande examine it in laboratory because it is often contaminated more than expected. These considerations lead to the obvious question: which facrtors are influencing the water quality of a lakes and a short discussion leads inevitably to the conclusions that the entire drainage area will have influence on the water quality of a lake. The overall conclusion is:lakes are open system and that are therefore dependent on all the activities in the entire dranage area. Ecosystems and open and they are therefore vulnerable.

\section{THE RECREATIONAL VALUE OF LAKES ARE VERY OBVIOUS}

Lakes are often utilized by the local population for a number of activities: angling, boating (Fig. 4), sailing, swimming, or just for enjoying nice nature. If the local population is not participating in these activities they certainly know about them or other family members or friends will utilize the lake in one way or another. This makes it relatively easy to persuade the population to do their utmost to protect the lake against pollution and other impacts. 


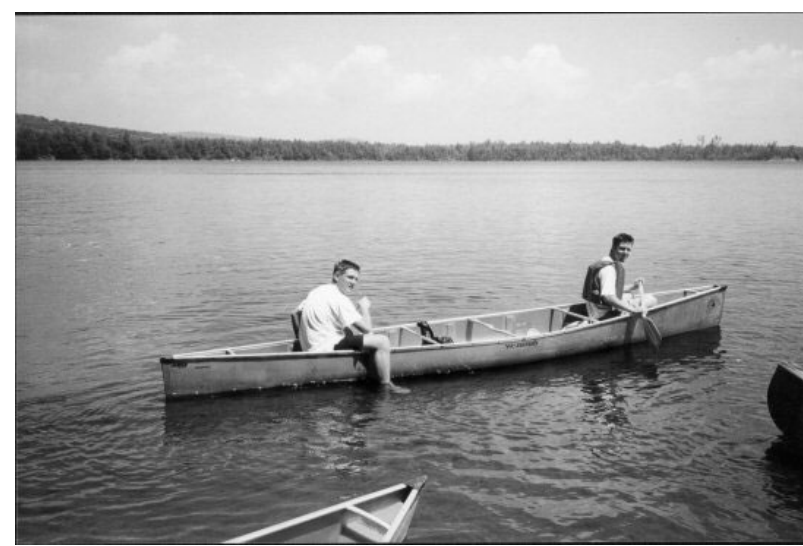

Fig. 4. Lakes have great recreational values. lems on the other side. The seven problems are eutrophication, water level decrease, acidification, siltation, salinization, contamination by toxic substances and introduction of exotic species. The human activities cause overexploitation of water resources, over use of land and increased emission to the environment due to the increased activities - and these three consequences of human activities lead furthermore to the seven pollution problems presented above. The seven pollution problems reduce our possibilities to utilize lakes as water resource, for navigation, for fishery and for recreational activities.

\section{THE SOCIAL-ECONOMIC VALUES ARE WELL ILLUSTRATED BY LAKES}

Questions such as "How do we use this and this

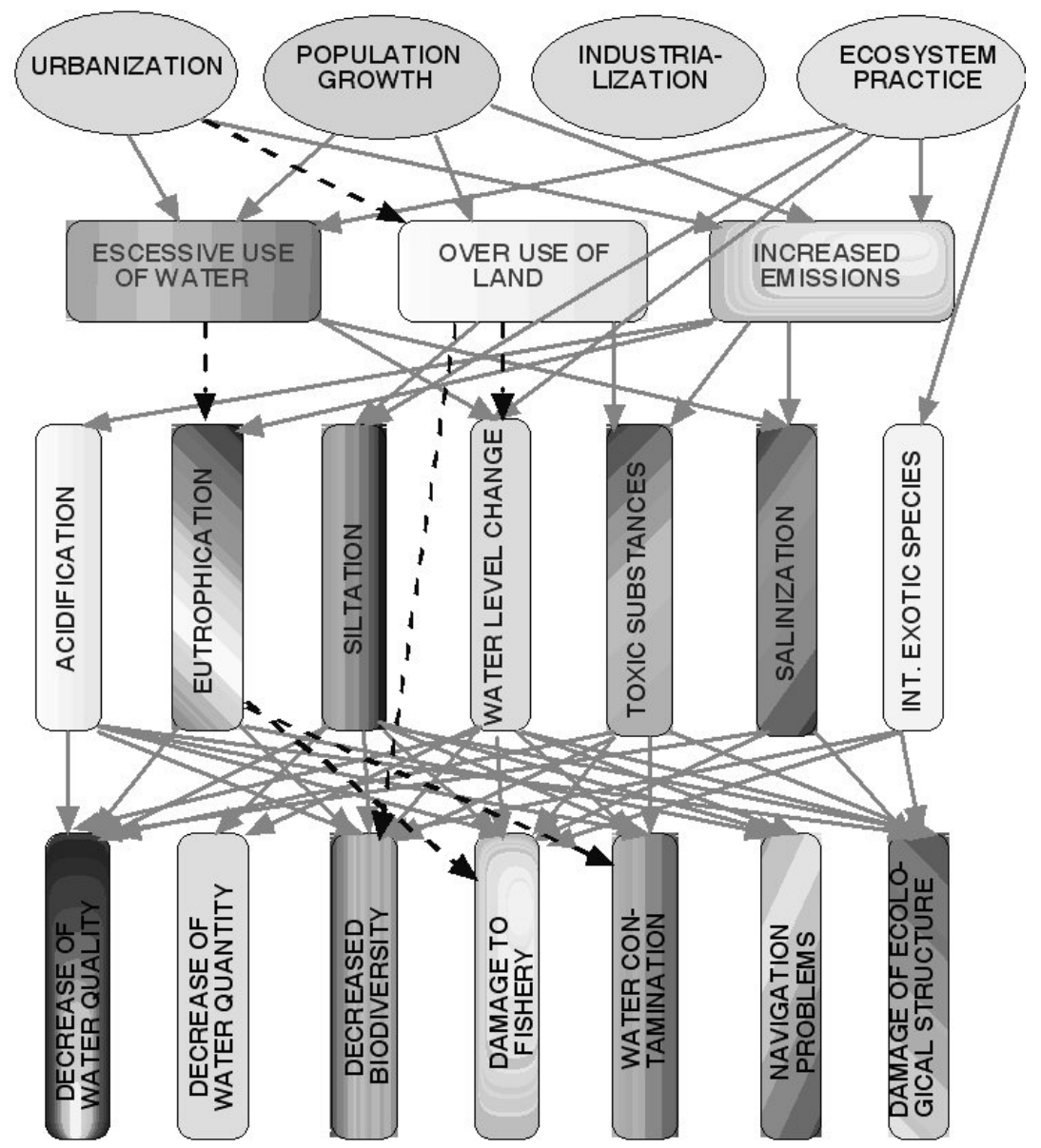

Fig. 5. The relationship between human activities and the seven pollution problems known from lakes.

\section{POLLUTION PROBLEMS ARE WELL ILLUSTRATED BY LAKES}

Figure 5, taken from Jørgensen et al. 2001, shows the relationship between human activities: urbanization, population growth, industrialization and ecosystem practice on the one side and seven lake pollution prob- lake?", "What are the benefit of this and this lake" or "What is the economic value of this and this lake?" lead very easily to a discussion about the social-economic values of a particular lake. Through this discussion the values are clearly revealed and all participants of the discussion will have a clear image of the value of the considered lake. The values of the considered lake are 
inevitably coming from the lake as a water resource, a fishery resource, needed for transportation, or/ and the recreational values of the lake, which may give an income by tourism. The recreational values are often very high in industrialized countries and therefore highly appreciated by the local population.

\section{CONCLUSIONS}

The ILEC school project which has briefly been discussed in this paper, has led to the following clear conlusions:
- Lakes are ideal to illustrate why we are concern with environmental problems

- Lakes are ideal to illustrate what environmental problems we meet in practice.

- Lakes are ideal to illustrate how various environmental problems are linked and interacting also with social and economic problems- a holistic approach is urgently needed.

\section{REFERENCES}

Jørgensen, S.E., M. Kawashima \& T. Kira. A Focus on Lakes, Rivers in Environmental Education. 